\title{
Analysis of Empowerment of Human Resources (Member) in Improving Career Development (Case Study at PT. HNI-HPAI Bussines Center (BC9) Subdistrict Sudirejo 1)
}

\author{
Nur Fadhilah Sadly \\ Universitas Islam Negeri Sumatera Utara, Indonesia \\ dyla.sadly@gmail.com
}

\begin{abstract}
Empowerment which means an effort needed to build power, by encouraging, motivating, raising awareness of the potential that is owned and trying to develop the potential of a member (member). In running a multi-level marketing business, PT.HNI-HPAI cannot be separated from human resources (members). A member (member) will not run optimally without the support of a leader/mentor. The research approach used in this research is qualitative. Research locations are areas or places that will be used as research targets. This research was conducted at PT. Herbal Medicine Alwahida Indonesia (HPAI) Bussines Center 9. $\mathrm{Jl}$. Clean Water, Ex. Sudirejo I Kec. Medan city of North Sumatra Province. Research time for this research was conducted from December 2019 to July. The strategy of the research that can be drawn 1) The upline's active role that nurtures the members can improve the quality and income of members every month. 2) Good communication between members (members) and the upline can increase the target of each member. 3) Fostering a sense of responsibility to all members by giving awards to members who are enthusiastic and motivated to always be active in their membership. And finally, there is a lot of training offered by the leadership / upline to members by holding training as interesting as possible to empower and manage members so that they are superior to members of competing companies. The results of the SWOT analysis that have been obtained in PT HNI-HPAI Business Center 9 Medan is The total score of each of the detailed factors, strength 3.25 , weakness 0.15 , opportunity 3.23 , threat 0.18 .
\end{abstract}

Keywords

empowerment of human resources, bussines center, improving career development

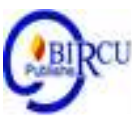

\section{Introduction}

PT. Herbal Penawar Alwahida Indonesia (HPAI) is a herbal company that runs its business with a Multi Level Marketing (MLM) system. However, the MLM business is only an alternative business method related to marketing and having a product with a different marketing method from other businesses. For this reason, in running a Multi Level Marketing (MLM) business, as much human resources as possible are needed.

In the Multi Level Marketing (MLM) business, members are human resources. Member as the main role in running the Multi Level Marketing (MLM) business. So more members are needed. In order for the Multi Level Marketing (MLM) business to quickly grow and develop in the network so that the work targets of a leader can be achieved.

In doing Multi Level Marketing (MLM) business, some leaders are only busy looking for new distributors (new members) without teaching them how to be successful in the business. In addition, they are also just busy selling as many products as possible without realizing that the profits they get are only short-term profits. For this reason, the 
Multi Level Marketing (MLM) system must have a strong network, in order to obtain longterm benefits.

So the leader (leader) must not only be able to route new members, but also must be able to empower members so that they are not only passive members, namely members who are only members but never transact and take action in developing the Multi Level Marketing (MLM) business. Because it requires good cooperation in running a Multi Level Marketing (MLM) business between members and leaders (leaders). In order to improve your career so you can get the rewards promised by the company.

Empowerment Human resources is an important thing, based on the results of observations made, at PT HNI-HPAI Business Center 9 Medan, that quality and competent members are still limited, Judging from the total number of members who join, namely 534 members, the passive members are 312 members. because it is still focused on one leader (leader). So that it is not in sync with the goal of building the PT HNI-HPAI business, namely creating entrepreneurship. Many members only register but don't spend, citing expensive and capital. So that automatically affects the performance of the leader (leader) and sales targets.

For this reason, every company leader must have strategies in terms of empowerment, so that they can compete with similar competitor companies. A clear mission statement is essential for setting goals and formulating a strategy. Strategy is important for the survival of a company to achieve effective and efficient company goals or objectives, the company must be able to face any problems or obstacles that come from within the company or from outside the company.

Business phenomenon with systems Multi Level Marketing a challenge for leaders at PT HNI-HPAI, especially Bussines Center 9 Medan. to create competent members, so that they can achieve maximum work performance and strengthen the growth of the Multi Level Marketing business at PT HNI-HPAI.

\section{Review of Literature}

\subsection{Empowerment}

Empowerment according to language comes from the word Daya which means energy/strength, process, method, act of empowering. Empowerment is an effort that builds people's power by encouraging, motivating and raising awareness of their potential and striving to develop it. Empowerment is defined as an effort to provide power (empowerment) or strengthening (strengthening) to the community. Sumodiningrat defines community empowerment as the ability of individuals who are united with the community in building the empowerment of the community concerned.

Ginandjar Kartasasmitha stated that empowerment is an effort to build that power, by encouraging, motivating, and raising awareness of its potential and trying to develop it. Therefore empowerment is directed at increasing the people's economy productively so that it can produce high added value and bigger income. Efforts to increase the ability to generate added value must at least improve access to four things, namely access to resources, access to technology, access to markets and access to demand.

So it can be concluded that empowerment is an effort to direct the community, to realize and build their own potential under the direction of the leadership. Empowerment is a process that runs continuously to increase the ability and independence of the community in increasing their standard of living, that effort can only be done by awakening their empowerment, to improve life above their own strength. The basic assumption used is that 
every human being has the potential and power to develop himself for the better. Thus, basically humans are active in efforts to increase their self-empowerment.

\subsection{Human Resources (Member)}

Human resources is the translation of "Human resources" but there are also experts who equate human resources with "manpower" (labor). Some people even equate the notion of human resources with personal (personnel, staffing, and so on). Human resources are the only resources that have a sense of feeling, desire, skills, knowledge, drive, power, and work (ratio, work and intention). All of these human resource potentials affect the organization's efforts to achieve goals. No matter how advanced technology, development for information, availability of capital and adequate materials, if without human resources it is difficult for the organization to achieve its goals.

The economic condition of the population is a condition that describes human life that has economic score (Shah et al, 2020). The basis of the Islamic economic philosophy states that human function both in the context of individuals and members of society is as the caliph of Allah on earth. This is the advantage of the Islamic development concept from other concepts, by placing the human role in a high and honorable place, but very responsible. Humans are God's representatives on earth to prosper the earth and are accountable to God regarding the management of the resources assigned to them.

Human resources are "employees who are ready, capable and alert in achieving organizational goals". As stated, the main dimension of the resource side is its contribution to the organization. Meanwhile, the main dimension of man is the treatment of his contribution, which in turn will determine the quality and capability of his life. Werdhiastutie et al (2020) stated that, The development of human resources should focus more on increasing productivity and efficiency. This can be realized because today's competition, especially among nations, is getting tougher and demands the quality of strong human resources as managers and implementers in an organization or institution. According to Irfansyah (2020), Organization is an important element and is needed in human life.

For this reason, resources are a tool to achieve goals or the ability to take advantage of existing opportunities. In general, organizational resources can be divided into two, namely human resources and non-human resources. Human resources include all individuals involved in the organization and each of them has its own role and function in achieving goals. Meanwhile, non-human resources consist of natural resources, capital, machinery, technology, material (raw materials), and others.

\subsection{Empowerment and Human Resource Management}

Management is the same as management. Management comes from the word manage which means controlling, administering, managing, and running. Whereas management is a process or method or act of managing, the process of carrying out certain activities by mobilizing the power of other people, a process that helps formulate policies and organizational goals, a process that provides supervision on all matters involved in implementing policies and achieving goals.

Management, namely the use of resources effectively to achieve goals. A manager is a person who organizes work or cooperation among various groups or a number of people to achieve goals or a person who is authorized and responsible for planning, organizing, leading, and controlling its implementation to achieve certain goals. So it can be concluded that, management is an activity of ordering, organizing, and thinking carried out by a 
person, so that he is able to sort, organize, and tidy up the things around him, know his priorities, and make his life always in harmony with others.

Empowerment is an effort to make human resources more responsible for their work which in turn can improve their performance. Empowering people can be done by moving them from a position that usually only does what they are told to, into a position that provides an opportunity to be more responsible So that human resources in the organization can further improve quality, loyalty and responsibility for the tasks they are assigned to, it is necessary to do something empowerment for employees in the organizational structure. In this case, the leader has a role to empower the employees so that the goals that have been set in an organization can be achieved. The process of empowerment and Human Resource Management must be carried out in various stages.

\subsection{Career}

Careers are interpreted variously by experts according to their scientific disciplines. According to Simamora, career is "a sequence of activities related to work and a person's behavior, values, and aspirations during that person's life span". Career planning is a deliberate process through which a person becomes aware of the attributes associated with a personal career and a series of steps throughout life contributes to career fulfillment.

Ekaningrum's opinion, Career is no longer defined as an institutional reward by increasing the position in the formal hierarchy that has been established in the organization. In the traditional paradigm, career development is often considered synonymous with preparation for higher level mobility, so that career will support the effectiveness of individuals and organizations in achieving their goals.

According to the Dalil $S$ "career is a process that is deliberately created by the company to help employees to help participation in the workplace". Meanwhile, Glueck stated that an individual career is a sequence of experiences related to the work experienced by a person during his work period. So that individual career involves a series of choices from various opportunities, but from an organizational point of view the career is a new task regeneration process.

Meanwhile, Ekaningrum's opinion on career is used to describe the people in each role or status. Careers are all positions (jobs) that have individual responsibilities. So it can be concluded that a career is a series or work achieved by a person within a certain period of time related to attitudes, values, behavior and motivation in individuals.

\section{Research Methods}

This research uses a qualitative approach. According to Denzin and Lincolyn states that qualitative research is research that uses a natural background, with the intention of interpreting the phenomena that occur and is carried out by involving various existing methods. The purpose of descriptive research is to describe accurately the characteristics of certain individuals, conditions, symptoms or groups or to find the spread (frequency) of a symptom and other symptoms in society.

The first reason, according to the author, is that qualitative research can directly describe the opinion of the object regarding the study being studied, because in this case the author will present the data in the form of word descriptions, according to the results of interviews obtained from resource persons. Another reason that the author can include here is because it makes it easier for the author to process the data. Therefore, according to the writer, qualitative research is more suitable for this thesis research. 
Research locations are areas or places that will be used as research targets. This research was conducted at PT. Herbal Medicine Alwahida Indonesia (HPAI) Bussines Center 9. Jl. Clean Water, Ex. Sudirejo I Kec. Medan city of North Sumatra Province. Research time for this research was conducted from December 2019 to July.

\section{Discussion}

Empowerment which means an effort needed to build power, by encouraging, motivating, raising awareness of the potential that is owned and trying to develop the potential of a member (member). In running a multi-level marketing business, PT.HNIHPAI cannot be separated from human resources (members). A member (member) will not run optimally without the support of a leader/mentor.

In the Multi Level Marketing system, PT.HNI-HPAI uses a break away, which means that the system in developing its network prioritizes width. The more frontliners, the bigger the bonus you receive. But the weakness is that an agent has to take care of everything himself because PT.HNI-HPAI's Multi Level Marketing system is sharia-based so that the sharia boards make regulations only consisting of 10 generations. So that they are able to manage their members effectively and efficiently.

With the Multi Level Marketing System PT.HNI-HPAI Business Center 9 Medan is automatically fully responsible for empowering its human resources (members) to become competent and outstanding members. In accordance with the mission of PT.HNI-HPAI is to produce Muslim entrepreneurs who can be proud of, both as marketers, network builders and producers. The empowerment and management strategies carried out by the leadership of PT.HNI-HPAI Business Center 9 Medan are as follows:

\subsection{Awareness}

In carrying out its business activities, PT.HNI-HPAI uses persuasive communication that emphasizes the concept of da'wah and spiritual services as well as health education rather than product offerings. This strategy is considered quite effective in attracting public sympathy, so that people with their own awareness will look for HPAI products according to their respective needs.

As human beings, the awareness that we were created to worship / serve Him must be embedded in the soul and mind. The implication and awareness of this is that every behavior and decision we make will always refer to seeking His pleasure. When we are given the burden of the mandate to manage human resources. Islam always invites its adherents to always stay in front of being the best, which can provide the greatest benefit for mankind.

When the awareness of a mandate has grown, there will be every effort to carry it out totally because the mandate that is carried is of course there is an accountability in the last day Likewise in the world of work. A worker who does not have any subordinates is still called a kholifah, because he is a leader for himself, the mandate that he carries is his own daily task. For a manager he must realize that there are employees who earn a living from him. Therefore, the leadership and management in essence hold the mandate to bring the lives of employees to be more physically and mentally prosperous. So that the responsibility is not only limited to achieving the company's productivity targets, but also how to relate to employees and their effects.

In this case the mentor (leader) educates members to form awareness of a potential customer for halal products that should be used by the Muslim community in particular. Because the market formed by PT.HNI-HPAI is Muslim. Such as the mission made by 
PT.HNI-HPAI to make the Muslim community entrepreneurs who can be proud of, making a place for the struggle to provide halal products for the Muslim community. For this reason, PT.HNI-HPAI not only opens awareness of halal products, but also in terms of the health of Muslims.

\subsection{Motivation}

In fulfilling various human interests, there are the most important elements, one of which is motivation. Basically, a person works because he wants to make ends meet. The urge to desire in one person is different so that human behavior tends to vary at work. Motivation is a condition or energy that moves employees who are directed or aimed at achieving the goals of the company organization. The mental attitude of employees who are pro and positive towards work situations is what strengthens their work motivation to achieve maximum performance, thus motivation means a condition that encourages or becomes a cause for someone to do an action or activity that takes place consciously.

The formation of motivation carried out by the leadership of PT.HNI-HPAI 9 Medan branch is divided into two forms of motivation first through thinking, namely by forming thoughts memberwith a need (need), urge (urge), desire (wish) and encouragement (motivate). Which leads to a decision that as a member must be active in running the chosen multi-level marketing business so that the results obtained such as salaries, bonuses are able to meet the needs of members.

Second, to motivate with the environment, people or material, namely by conducting coaching between memberPT.HNI-HPAI which already has income after joining as a member. One form of coaching activities carried out is regular and non-regular Tibunnabawi Herbs Lectures (KHT), home sharing and various skills training guided by herbal experts (herbalists) and HPAI motivators from the central and regional levels.

\subsection{Amenities}

Facilities are anything that can facilitate and facilitate the implementation of a business and constitute facilities and infrastructure needed to carry out or facilitate an activity. The central PT.HNI-HPAI company also provides pleasant facilities for members. For example, facilities, free Umrah, old age insurance, education guarantees and so on. The company has provided these facilities, to increase the enthusiasm and pleasure of members, so that their enthusiasm for work can also be increased. However, these facilities are provided for members who have reached LED positions. Meanwhile, the facilities that can be provided by PT.HNI-HPAI 9 Medan branch are giving gifts of HNI-HPAI products, for members who achieve sales targets. As well as providing opportunities to members by allowing goods without capital on the condition that only one day. This is an opportunity for members who do not have capital.

Facility itself can be interpreted as convenience and can also mean tools or physical form (facilities and infrastructure). What is meant by work facilities is everything that is contained in a company that is occupied and enjoyed by employees, either in a direct relationship with work or for the smooth running of work.

\subsection{Mutual Cooperation}

Human life is inseparable from social interactions with one another because by nature humans are social beings who cannot live alone but need the help of others in various matters, such as socializing, working, helping to help, community service, security and others. Gotong royong, as a form of social solidarity, is formed because of assistance from other parties for personal or group interests, so that there is a loyal attitude of each citizen as a unit. 
Mutual cooperation as a form of cooperation between individuals and groups forms a norm status of mutual trust to collaborate in dealing with problems of mutual interest. This form of mutual cooperation is a form of social solidarity. Gotong royong as a form of social solidarity, is formed because of the assistance from other parties for personal or group interests, so that there is a loyal attitude of every citizen as a unit.

The mutual cooperation attitude carried out by PT.HNI-HPAI 9 Medan branch in recruiting or in promoting and educating leaders / mentors will provide assistance to active members by helping to turn the network on so that it grows and develops, so that it can achieve the target. In this case, mutual cooperation between members or members to the mentor is the ultimate weapon carried out by PT.HNI-HPAI 9 Medan branch in building networks. So that all members who really want to work will get maximum results.

A company can only develop and move forward if the company is always responsive to changes in the environment, technology and science. The challenges and opportunities for a company, both from within and without, are complex. Therefore, companies must be able to adapt their workforce, especially from a qualitative perspective, to these changes by equipping their workforce with various knowledge and skills through training and development programs.

Training and development is very important for prospective new members and existing employees. Training is an activity to improve current performance and future performance. Meanwhile, development is a process to improve the progress of human resources in helping achieve company goals, so as to improve the quality of the products produced.

The leaders or leaders are very aware of the importance of training and development for members so that members can develop competencies and abilities in carrying out their work. Training and development carried out by PT.HNI-HPAI BC 9 Medan, namely through in-company training as follows:

a) Following the Tabunnabawi Herba lecture presented by the central PT.HNI-HPAI, holding seminars by inviting members through various branches owned by PT.HNIHPAI. The seminar will discuss products, business systems, and royalties.

b) Participating in the home sharing was gathering several people to listen to the mentors explaining the product, business system, it's just that the coverage of participating members was only members who were under the auspices of PT.HNI-HPAI BC 9 Medan. It can also be done at the members' houses.

c) Attend training, such as seminars created by successful mentors, by sharing stories and experiences to motivate members who want to achieve the same success. By carrying out training like this, it is hoped that it will become one of the motivations for the members who have just joined and for the old members.

Compensation is an award given by a company in return for work performance given by the workforce. Compensation is an important factor influencing how and why people work for one company and not another company. The company must be competitive enough to provide some compensation for hiring, firing and rewarding the performance of each individual in the company. Usually members receive bonuses if they run their business well, do a lot of recruiting members and selling products. Then automatically the network business that is carried out will generate a bonus or royalty that has been determined by PT.HNI-HPAI. The bonus system is based on the members' achievement based on the rank and status of the stock agent held. The explanation is as follows: 
Table 1. System of giving bonuses based on rank

\begin{tabular}{|c|l|c|c|}
\hline No. & \multicolumn{1}{|c|}{ Position / rank } & Market & Profit \\
\hline 1 & Ordinary Agent (AB) & & $10 \%$ \\
\hline 2 & Manager (M) & SC & $20 \%$ \\
\hline 3 & Senior Manager (SM) & DC & $23 \%$ \\
\hline 4 & Executive Manager (EM) & DC & $26 \%$ \\
\hline 5 & Director (D) & DC & $29 \%$ \\
\hline 6 & Senior Director (SD) & DC & $32 \%$ \\
\hline 7 & Executive Director (ED) & AC & $35 \%$ \\
\hline 8 & Loyal Executive Director (LED) & BC & $5 \%$ \\
\hline
\end{tabular}

In Islam, human resource management refers to what the Prophet Muhammad SAW exemplified based on the Islamic concept of man himself. The first concept: humans were created to worship God. Therefore all human activities must be a form of worship, worship in a broad sense, not just ritual worship. Every human activity can have the value of worship if it is intended to seek the pleasure of God. Having a good society is worship, working hard is worship, even sleeping can be of worship value. Second concept: humans are khalifatullah fil ardhli- God's representative on earth, whose job is to prosper the earth. The consequence of these two concepts is that all human activities will be assessed and accounted for in the afterlife. With this concept, Islam views that human problems are not trivial problems. Islam strives for human resources to participate in the prosperity of the earth within the sphere of devotion to God by making optimal use of the potential that has been bestowed by God.

In terms of recruitment\& selection, he places great importance on professionalism. He said, "If an affair is left to someone who is not an expert, then wait for the (destruction) time." (Narrated by Bukhari and Ahmad). Rasulullah also said, "Whoever appoints someone as an employee of a people, even though in that people there is someone who is pleased by Allah (capable, pious and believing) then he has betrayed Allah, His Messenger and other believers. (Narrated by al-Hakim).

Human resources who have and hold religious values will be more resilient spiritually. Thus it will have more spiritual responsibility for science and technology. WithThus the development of human resources based on the concept of Islam is to form human beings with noble morals, who always worship Allah who spreads mercy for the universe and pays devotion to Allah. This is the direction of HR development according to the Islamic concept Employees are exploited in such a way that they are truly afraid to convey ideas, ideas, expectations of the company.

\section{Conclusion}

The results of the SWOT analysis that have been obtained in PT HNI-HPAI Business Center 9 Medan is The total score of each of the detailed factors, strength 3.25, weakness 0.15 , opportunity 3.23 , threat 0.18 . Then it is known that the difference in the total score of the strength and weakness factors is (+) 3.10, obtained from the strength score reduced by the weakness score, namely 3.25 minus 0.15 . While the difference between the total score of the opportunity and threat factor is $(+) 3.05$, which is obtained from the opportunity score reduced by the threat score, namely 3.23 minus 0.18 . So the coordinate point on the empowerment and management of human resources members (members) of PT HNI-HPAI Business Center 9 Medan is (3.10: 3.05). It clearly shows that the members of PT HNI- 
HPAI Bisnis Center 9 Medan are in the growth quadrant where this quadrant is a very profitable situation. Members (members) have opportunities and strengths so they can take advantage of existing opportunities. This strategy that must be applied in this condition is to support an aggressive growth policy (Growth Oriented Strategy). The total score of internal business strength has a number of 3.40 and the total score of industrial attractiveness is 3.41, so the Internal and External matrix shows that in cell number 1, Growth which means that is designed to achieve growth through concentration can achieve vertical integration by means of backward integration, where the main strategy for companies that have a strong competitive market position (high market share) in an industry with high attractiveness. And the strategy taken is first, The upline's active role that nurtures the members can improve the quality and income of members every month. Second, good communication between members (members) and the upline can increase the target of each member. Third, Fostering a sense of responsibility to all members by giving awards to members who are enthusiastic and motivated to always be active in their membership. And finally, there is a lot of training offered by the leadership / upline to members by holding training as interesting as possible to empower and manage members so that they are superior to members of competing companies.

\section{References}

Ahmad Wardi Muslich. (2015). Fiqh Muamalat, Cet. ke-III, (Jakarta: Amzah)

Ahmad Tanzeh. (2011). Metode Penelitian Praktis, (Yogyakarta: Teras)

Antonio, Muhammad Syafi'I. (2005). Mengenal MLM Syari'ah Dari Halal-Haram, Kiat Berwirausaha, Sampai dengan Pengelolanya. (Tangerang: Qultum Media)

Amin, Muhamad. "Strategi Pemasaran Mlm (Multi Level Marketing) Perspektif Ekonomi Islam (Studi Kasus Pada PT. Natural Nusantara Cabang Purwokerto)", IAIN Purwokerto, Purwokerto.

Artmanda W Frista. Kamus Lengkap Bahasa Indonesia, (Jombang : Lintas Media, tt)

Aziz Hasan. (2018). Pembangunan Ekonomi dan Pemberdayaa Masyarakat, (Makassar: Pustaka Taman Ilmu).

Alma, Buchari Donni Juni Priansa. (2009). Manajemen Bisnis Syariah, (Bandung:Alfabeta)

Bagong Suryanto dan Sutinah. (2000). Metode Penelitian Sosial Berbagai Alternatif Pendekatan, (Jakarta: Prenada Media)

Bakir, R. Sutyo. (2009). Kamus Lengkap Bahasa Indonesia, (Tanggerang: Karisma Publishing Group)

Edi Suharto. (2005). Membangun Masyarakat Memberdayakan Rakyat, (Bandung: Refika Aditama)

Daniel Sukalele, "Pemberdayaan Masyarakat Miskin Di Era Otonomi Daerah", dalam wordpress.com/about/pemberdayaan-masyarakat-miskin-di-era-otonomi-daerah

Darni. (2014). Pengantar Bisnis (Pekanbaru: Benteng Media)

Departemen Agama Republik Indonesia. (2014). Al-Quran dan Terjemahnya, Jakarta: PT. Hati Emas.

Fahmi, Irham. (2014). Prilaku Organisasi Teori, Aplikasi, dan Kasus, (Bandung: Alfabeta)

Freddy Rangkuti. (2004). Analisis SWOT Teknik Membedah Kasus Bisnis, (Jakarta: Gramedia Pustaka Utama)

Hasan, Aziz. (2018). Pembangunan Ekonomi dan Pemberdayaa Masyarakat, (Makassar: Pustaka Taman Ilmu) 
Hasan, Engking Soewarman. (2002). Strategi Menciptakan Manusia Yang Bersumber Daya Unggul, (Bandung: Pustaka Rosda Karya)

HPAI. (2019). Panduan Sukses HNI-HPAI, Jakarta.

Huda Nurul dkk. (2015). Ekonomi Pembangunan Islam, Kencana, Jakarta.

Irfansyah. (2020). The Duties and Functions Performance of Aceh Human Resources Improvement Institutions in Scholarship Study Program Implementation in Aceh Government. Britain International of Humanties and Social Sciences (BIoHS) Journal, Vol. 2, No. 1, Page: 160-165.

Jusmaliani. (2011). Pengelolaan Sumber Daya Insani, Jakarta: Bumi Aksara.

Jawwad, Muhammad Abdul. (2004). Menjadi Manajer Sukses, (Jakarta: Gema Insani)

J David Hunger dan Thomas L. (1996). Manajemen Strategis. (Yogyakarta: Andi)

Kartasasmita, Ginanjar. (1997). Pembangunan Untuk Rakyat: Memadukan Pertumbuhan dan Pemerataan, (Jakarta: Cides)

Kadir A. (2010). Hukum Bisnis Syariah Dalam Al-Qur'an.(Palu: Amzah)

Karim Adiwarman. (2002). Ekonomi Mikro Islami (jakata: III T)

Kismono, Gugup. (2012). Bisnis Pengantar, Yogyakarta: BPFE.

Kotler Philip dan Armstrong. (2007). Marketing Management, Alih Bahasa: Benyamin Molan, Manajemen Pemasaran, (Jakarta: Indeks)

Lexy J. Moleong. (1989). Metodologi Penelitian Kualitatif (Bandung: Remaja Rosda Karya)

Mardi Yatmo Hutomo. Pemberdayaan Masyarakat dalam Bidang Ekonomi: Tinjauan Teoretikdan Implementasi. Makalah Seminar Sehari Pemberdayaan Masyarakat yang diselenggarakan Bappenas, tanggal 06 Maret 2000 di Jakarta. Di akses dari www.bappenas.go.id.

Moleong, Lexy. (2001). Metodologi Penelitian Kualitatif, (Bandung: PT. Remaja Rosada Karya)

Muahammad Fuad al-Baqi', Mu'jam al-Mufaras al-Fad al-Quran al-Karim, t.t, DAR AlfIkr, hlm. 587-558 3Hatta Abdul Malik, Jurnal Dimas, Pemikiran Agama untuk Pemberdayaan, (Semarang: LPM IAIN Walisongo, 2012),

Muhamad Nazir. (1983). Metode Penelitian, (Jakarta: Ghalia Indonesia)

Muslich Ahmad Wardi. (2015). Fiqh Muamalat, Cet. ke-III, (Jakarta: Amzah)

Ndraha, Taliziduhu. (2002). Pengantar Teori Pengembangan Sumber Daya Manusia, Rienika Cipta, Jakarta.

Pusat Bahasa Departemen Pendidikan Nasional. (2002). Kamus Besar Bahasa Indonesia, (Jakarta: Balai Pustaka).

R. Sutyo Bakir. (2009). Kamus Lengkap Bahasa Indonesia, Tanggerang: Karisma Publishing Group.

Ramly, Zulchaidir B. Firly. (2017). Dwilogi the Master Book to be the Best Market Leader, (Jakarta: FightheR Management)

Sadono Sukirno. (2004). Pengantar Bisnis : Edisi Pertama, (Jakarta: PradanaMedia Group)

Sahrani Sohari, Ru'fah Abdullah. (2011). Fikih Muamalah untuk Mahasiswa UIN/IAIN/STAIN/PTAIS DAN Umum, (Bogor: Ghalia Indonesia).

Sedarmayanti. (2000). Sumber Daya Manusia dan Produktivitas Kerja. (Bandung: Mandar Maju)

Shah, et al. (2020). The Development Impact of PT. Medco E \& P Malaka on Economic Aspects in East Aceh Regency. Budapest International Research and Critics InstituteJournal (BIRCI-Journal), Vol 3, No 1, Page: 276-286.

Soetomo. (2009). Pengembangan Masyarakat, (Yogyakarta: Pustaka Pelajar). 
Suharto Edi. (2006). Membangun Masyarakat Memberdayakan Rakyat, (Bandung : Refika Aditama)

Sutrisno, Edy. (2009). Manajemen Sumber Daya Manusia, Kencana, Jakarta.

Werdhiastutie, et al. (2020). Achievement Motivation as Antecedents of Quality Improvement of Organizational Human Resources. Budapest International Research and Critics Institute-Journal (BIRCI-Journal), Vol 3, No 2, Page: 747-752.

Wibowo. (2013). Perilaku dalam Organisasi, (Jakarta: PT RajaGrafindo Persada)

Zubaedi. (2007). Wacana Pembangun Alternatif: Ragam Prespektif Pembangunan dan Pemberdayaan Masyarakat, Jakarta: Ar Ruzz Media. 